\title{
HIV/HCV Co-Infection in a Teaching Hospital in Nigeria: A Short Review
}

\section{Mabayoje VO}

Department of Haematology, Lautech Teaching Hospital, Nigeria

Received: October 12, 2015; Accepted: February 29, 2016; Published: March 06, 2016

\section{Corresponding author: V O Mabayoje}

Co-infection and opportunistic infections are a major source of concern in HIV positive patients on Highly Active Antiretroviral Therapy (HAART) [1]. The hepatitis viruses are of particular importance and also the re-emergence of Tuberculosis in parallel with incidence of HIV [2]. Hepatitis C Virus Co- Infection (HCV) with HIV though less common than hepatitis B virus co-infection with HIV is considered a major source of public health concern $[3,4]$. This is due to the effect of HIV on the life cycle of HCV and subsequently on the hepatic system.

The mechanisms underlying accelerated liver disease in hepatotropic viruses/HIV co-infected individuals are poorly understood but may include the following: direct viral effects on hepatocytes and hepatic stellate cells, and immunologic alterations such as immune activation, apoptosis and diminished $\mathrm{HCV}$ specific T-cell responses. Also to be considered is the liver toxicity of antiretroviral drugs and the burden of metabolic disease contributing to a faster progression of liver fibrosis in HIV/ HCV co-infection. HIV immune activation induces cytokine changes (e.g., IL -4, IL -5 , and IL -13 , TGF - $\beta$ ) that increase liver inflammation and fibrosis [5-7].

Co-infection also increases apoptosis of hepatocytes through a Fas/Fas L pathway that could account for accelerated liver disease. Accumulation of cytotoxic CD8 T cells in the liver that increases inflammatory mediators in co-infected compared to $\mathrm{HCV}$ monoinfected patients may also lead to increased tissue damage in co-infected patients. Recent evidence shows HIV specific CD8 T-cells accumulate in the liver in co-infection and produce TNF $-\infty$, which is associated with liver fibrosis $[8,9]$.

The reported prevalence of HIV/HCV co infection notoriously varies significantly among studies even within the same geographical location, suggesting that an environmental factor probably hygiene is operating but yet to be identified. HIV and $\mathrm{HCV}$ are both transmitted through parental, sexual and vertical exposure but differ in the transmission efficiencies of these routes. The parenteral routes being more efficient for infection of HCV hence nosocomial infections and intravenous drug users being more susceptible to HCV infection than HIV.

However it appears though that the effects of co infection with these viruses on the liver are somewhat limited to developed countries or the western world. This could be considered to be a wide assumption however numerous reports of severe hepatic damage have been cited in Europe and America but very little tunjimabs@gmail.com

\begin{abstract}
Department of Haematology, Lautech Teaching Hospital, Osogbo, Osun State, Nigeria.
\end{abstract}

Tel: +2348033294874

Citation: Mabayoje VO. HIV/HCV Co-Infection in a Teaching Hospital in Nigeria: A Short Review. J HIV Retrovirus. 2016, 2:1.

from Africa [10-12]. The majority of studies carried out in Africa are mainly descriptive and do not reveal actual incidence rates or occurrence of liver disease as opposed to HCV prevalence in these patients some studies even report hepatoxicity as being uncommon [13-15]. In a study carried out in southwest Nigeria in 2013, the prevalence rate of HCV among HIV patients in our facility was found to be $23.3 \%$ [16]. It is generally accepted that one third of HIV patients are co-infected with HCV. Three years later of all the co-infected patients screened at the time none have developed any significant clinically overt liver damage. The main findings among them is a persistently low CD4 count despite being on highly active antiretroviral therapy (HAART including Zidovudine, Lamivudine and Nevirapine) which is not unexpected and mildly raised liver enzymes (serum aspartate transaminase and serum alanine transaminase). None were on treatment for the HCV component of the co-infection. Though liver biopsy and histology is the gold standard for detecting liver fibrosis it is invasive and has associated complications such as pain and bleeding. It may be necessary however to further subject these patients to more studies such as AST to platelet ratio index (APRI) and transient hepatic elastography a simple non invasive method which measures liver stiffness [17]. The results of all these tests combined may give a clearer picture. The limitation here is a pernicious lack of funds despite being a country with vast oil fields and now unfortunately the price of oil is at an all-time low to further compound the problem of health care among this subset of patients. 


\section{References}

1 Koziel MJ, Peters MG (2007) Viral hepatitis in HIV infection.N Engl J Med 356: 1445-1454.

2 Kim JH, Psevdos G, Suh J, Sharp VL (2008) Co-infection of hepatitis $B$ and hepatitis $C$ virus in human immunodeficiency virus-infected patients in New York City, United States.World J Gastroenterol 14: 6689-6693.

3 Crockett SD, Keeffe EB (2005) Natural history and treatment of hepatitis $B$ virus and hepatitis $C$ virus coinfection.Ann Clin Microbiol Antimicrob 4: 13.

4 Hoffmann CJ, Thio CL (2007) Clinical implications of HIV and hepatitis B co-infection in Asia and Africa.Lancet Infect Dis 7: 402-409.

5 Operskalski EA, Kovacs A (2011) HIV/HCV co-infection: pathogenesis, clinical complications, treatment, and new therapeutic technologies. Curr HIV/AIDS Rep 8: 12-22.

6 Rotman Y, Liang TJ (2009) Coinfection with hepatitis C virus and human immunodeficiency virus: virological, immunological, and clinical outcomes.J Virol 83: 7366-7374.

7 Roe B, Hall WW (2008) Cellular and molecular interactions in coinfection with hepatitis $C$ virus and human immunodeficiency virus.Expert Rev Mol Med 10: e30.

8 Kim AY, Chung RT (2009) Coinfection with HIV-1 and HCV--a one-two punch.Gastroenterology 137: 795-814.

9 Vali B, Yue FY, Jones RB, Sheth PM, Kaul R, et al. (2008) HIV-specific
T-cells accumulate in the liver in HCV/HIV co-infection.PLoS One 3: e3454.

10 Hernandez MD, Sherman KE (2011) HIV/hepatitis C coinfection natural history and disease progression.Curr Opin HIV AIDS 6: 478-482.

11 Spengler U (2011) Management of end-stage liver disease in HIV/ hepatitis C virus co-infection. Curr Opin HIV AIDS 6:527-533.

12 Maalouf NM, Zhang S, Drechsler H, Brown GR, Tebas P, et al. (2013) Hepatitis $C$ co-infection and severity of liver disease as risk factors for osteoporotic fractures among HIV-infected patients.J Bone Miner Res 28: 2577-2583.

13 Ladep NG, Agaba PA, Agbaji O, Muazu A, Ugoagwu P, et al. (2013) Rates and impact of hepatitis on human immunodeficiency virus infection in a large African cohort. World J Gastroenterol 19:1602-1610.

14 Agbaji O, Thio CL, Meloni S, Graham C, Muazu M, et al. (2013) Impact of hepatitis $C$ virus on HIV response to antiretroviral therapy in Nigeria.J Acquir Immune Defic Syndr 62: 204-207.

15 Akinbami AA, Oshinaike OO, Adeyemo TA, Adediran A, Oshikomaiya $\mathrm{BI}$, et al. (2010) Seroprevalence of hepatitis C infection in HIV patients using a rapid one-step test strip kit.Nig Q J Hosp Med 20: 144-146.

16 Mabayoje VO, Muhibi MA, Akindele RA, Akinleye CA, Mabayoje PS, et al. (2013) Hepatitis C virus co-infection among people living with HIV/AIDS in a Nigerian Teaching hospital. HIV and AIDS Review 12 : 102-105.

17 Leonardo de Lucca Schiavon, Janaína Luz Narciso-Schiavon, Roberto José de Carvalho-Filho (2014) Non-invasive diagnosis of liver fibrosis in chronic hepatitis C World J Gastroenterol. ; 20: 2854-2866. 